\title{
TABLETS FROM THE SIPPAR LIBRARY
}

\author{
VII. THREE WISDOM TEXTS
}

\author{
By A. R. GEORGE and F. N. H. AL-RAWI
}

To Professor W. G. Lambert

The present article in the series begun in Iraq 52 and continued in Volumes 56-8 offers three tablets from the Sippar library which add to our knowledge of the genre of Babylonian literature known today as "wisdom": a manuscript of Tablet I of Ludlul bel nēmeqi (The Poem of the Righteous Sufferer), a copy of the great Šamaš Hymn, and a tablet inscribed with a small collection of proverbs. ${ }^{1}$

\section{Ludlul I}

Since W. G. Lambert's edition of Ludlul in Babylonian Wisdom Literature several further sources for Tablet I of this text have been identified. Most notable of these is the manuscript from Nimrud, which plugged the gap between lines 12 and 41 and partly filled out the fragmentary end of the text. ${ }^{2}$ Being complete save for a few lines either side of its bottom edge, the new Sippar tablet provides further improvements in both places. It contains $11.1-50$ on its obverse and 62-120 on its reverse. The scribe failed to judge his spacing accurately, with the result that towards the end of the tablet he was forced to double up a whole sequence of lines, the twelve lines 105-16 occupying only six lines on the tablet. But even this was not enough, and 11. 117-20 and the catchline (= II 1) had to be written on the top edge of the tablet. Unfortunately this left no room for a colophon, unless one is inscribed on the left edge. For the moment we are unable to ascertain whether this might be so. The tablet came from Niche $1 \mathrm{D}$ of the library - that is the fourth from the ground in the row furthest left on the south-east wall; ${ }^{3}$ it measures $14.7 \times 7.5 \times 3.1 \mathrm{~cm}$.

The new manuscript offers important new readings and significant variants in the following lines: $14,18-20,25,26,29 / / 31,36-44,66,67,72-4,76,87,88,112-20$. The cuneiform copy has been made by $\mathrm{Dr}$ Al-Rawi from his photographs, aided by a transliteration of the tablet and notes he wrote in Baghdad in the 1980s. His transliteration was made before the tablet was baked, the photographs after. Since slight damage to the tablet was sustained during baking, the transliteration is witness to a fuller text. In the present edition signs and parts of signs that were present

\footnotetext{
${ }^{1}$ Tablets from the Sippar library are published by generous leave of the University of Baghdad and the Directorate of Antiquities and Heritage, Baghdad. The authors also record their gratitude to the British School of Archaeology in Iraq for its continued financial aid in support of Dr Al-Rawi's work.

${ }^{2}$ D. J. Wiseman, "A new text of the Babylonian Poem of the Righteous Sufferer", AnSt 30 (1980), pp. 101-7 (11. 1-46, 91-120). Wiseman's copy has been republished, along with photographs and Black's copy of a previously unpublished fragment of the same tablet (11. 48-68, 69-85), as Text No. 201 in D. J. Wiseman and J. A. Black, Literary Texts from the Temple of Nabû (CTN 4; London, 1996); see also pp. 29-30. To the latter go our thanks for allowing us to use his copy in advance of publication. Other sources of Ludlul I identified since 1960 include BM 61433, an exercise tablet published by E. Leichty, Finkelstein Mem. Vol., p. 145 (11. 88-92); 79-7-8, 225 (11. 26-30, 97-100), of which some lines were quoted by W. L. Moran, "Notes on the hymn to Marduk in Ludlul bèl nêmeqi", JAOS 103 (1983), pp. 255-60; and, all unpublished, K 1757+18963 (1l. 51-5), BM 66345 (1l. 6-21), BM 68444 (1l. 38-53), BM 73592 (11. 21-38, 85-100), and the exercise tablet BM 93079 (11. 55-8). The most recent translations are those of $\mathrm{W}$. von
}

Soden, "Der leidende Gerechte", in W. H. Ph. Römer and W. von Soden, Weisheitstexte 1 (TUAT III/1; Gutersloh, 1990), pp. 110-35, and of B. R. Foster, Before the Muses (Bethesda, Md, 1993), pp. 308-25, repeated in id., From Distant Days (Bethesda, Md, 1995), pp. 298-313. Foster's translation was revised in the light of the tablet published here for the second edition of Before the Muses (Bethesda, Md, 1996), pp. 306-23; also in W. W. Hallo and K. Lawson Younger, Jr (eds.), The Context of Scripture I. Canonical Compositions from the Biblical World (Leiden, 1997), pp. $486-92$.

${ }^{3}$ See the photographic panorama of the library chamber published by the late Walid al-Jadir in L. De Meyer and H. Gasche (eds.), Mésopotamie et Elam (CRRA 36; Ghent, 1991), p. 196, Fig. 2b. In the case of this niche a little information about its contents is already available. Apart from the piece of Ludlul I published here, manuscripts of the following compositions or genres were among those stored there (see Iraq 52 [1990], p. 149 ${ }^{1}$ ): Ea I, V and VIII; the bilingual of Nebuchadnezzar I; SB Atra-hasis IV (see Iraq 58 [1996], pp. 147-90; note that the library's copies of Tablets I, II and $\mathrm{V}$ of this text came from another niche, $6 \mathrm{~A}$ ); lung omens (šumma ubān hašê); and šumma àlutype omens. 


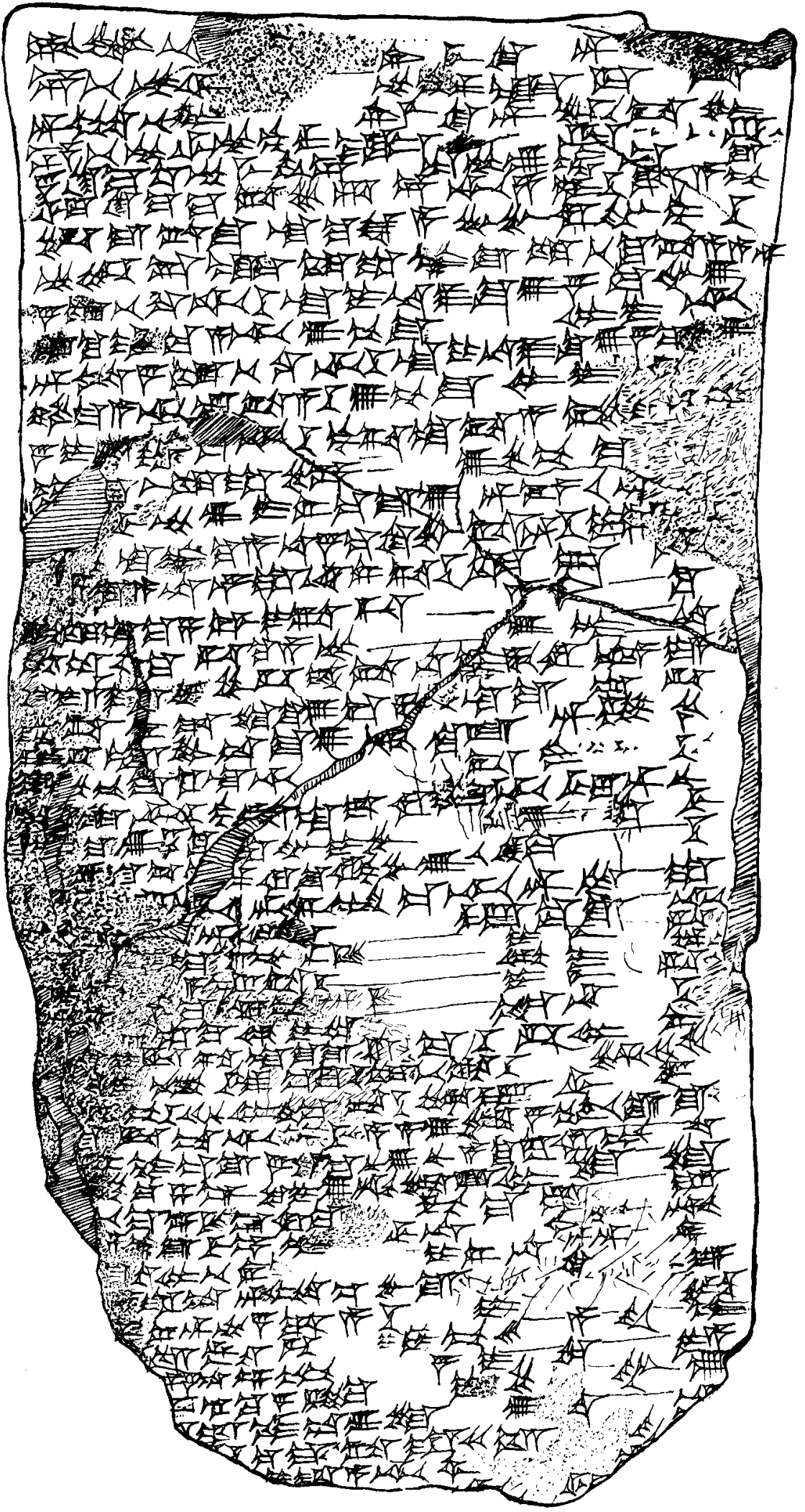

Fig. 1 Sippar Library 1.D.4, obverse: Ludlul I 1-50. 


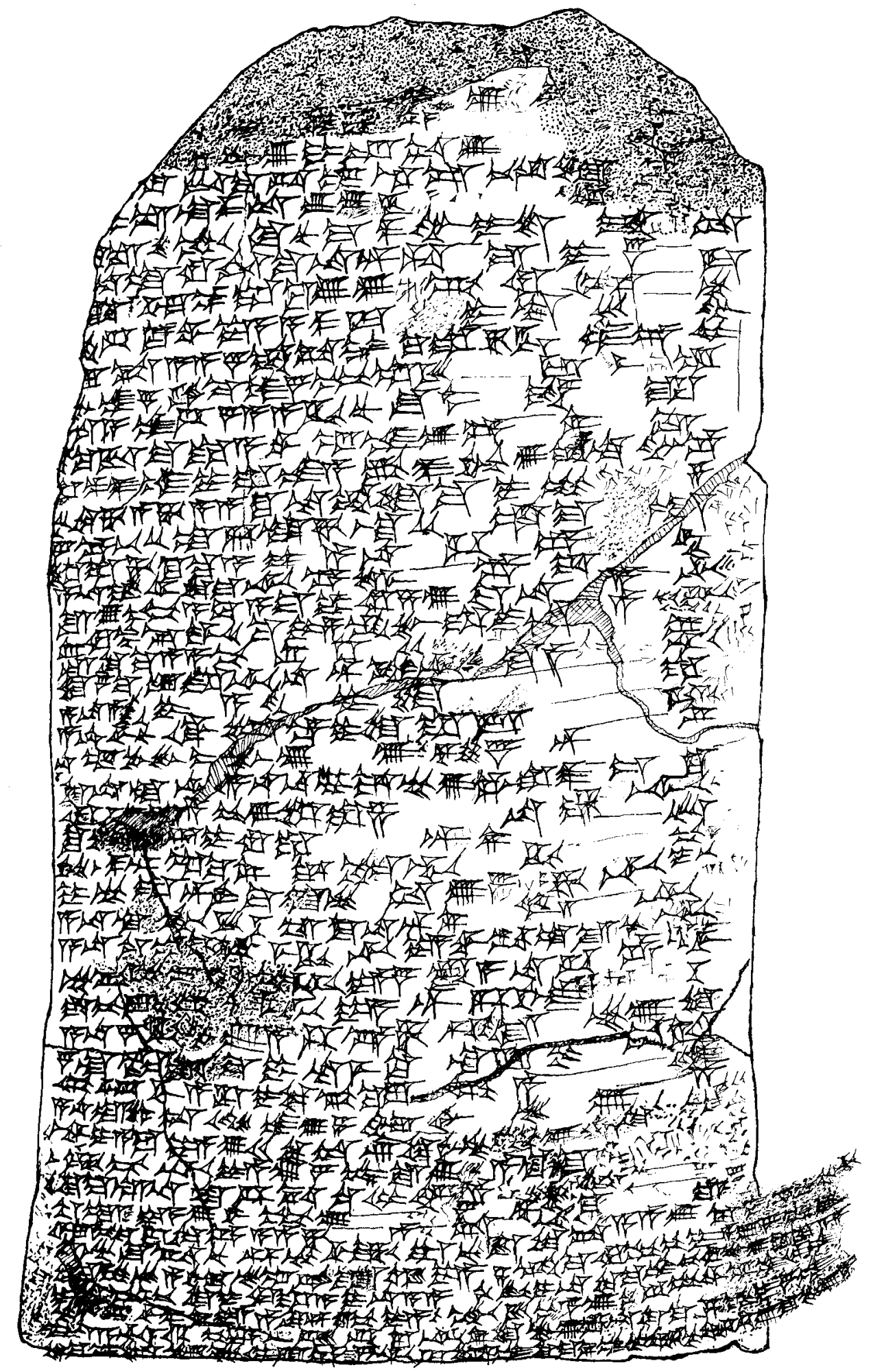

Fig. 2 Sippar Library 1.D.4, reverse: Ludlul I 62-116. 


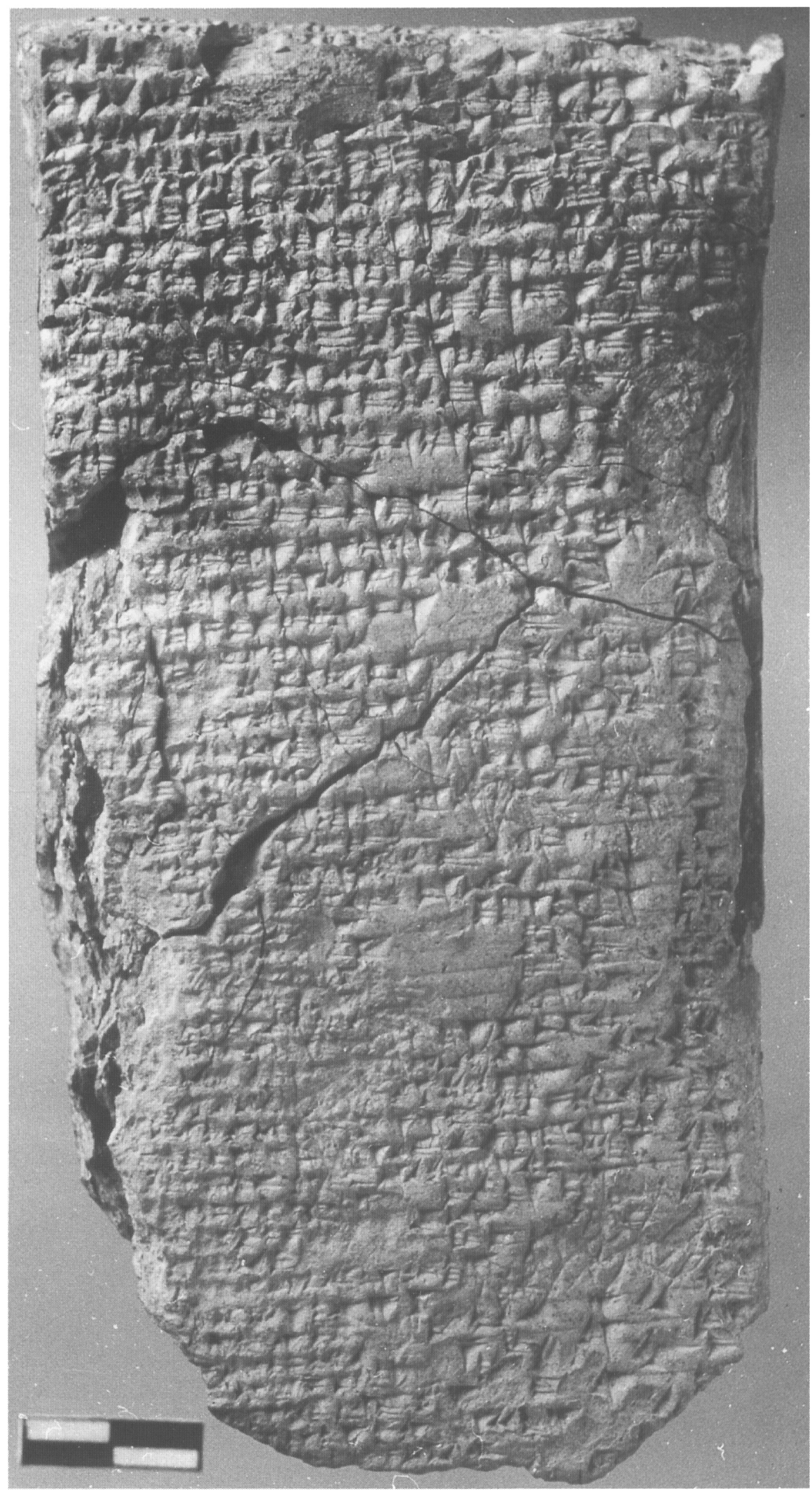

Fig. 3 Sippar Library 1.D.4, obverse: Ludlul I 1-50. 


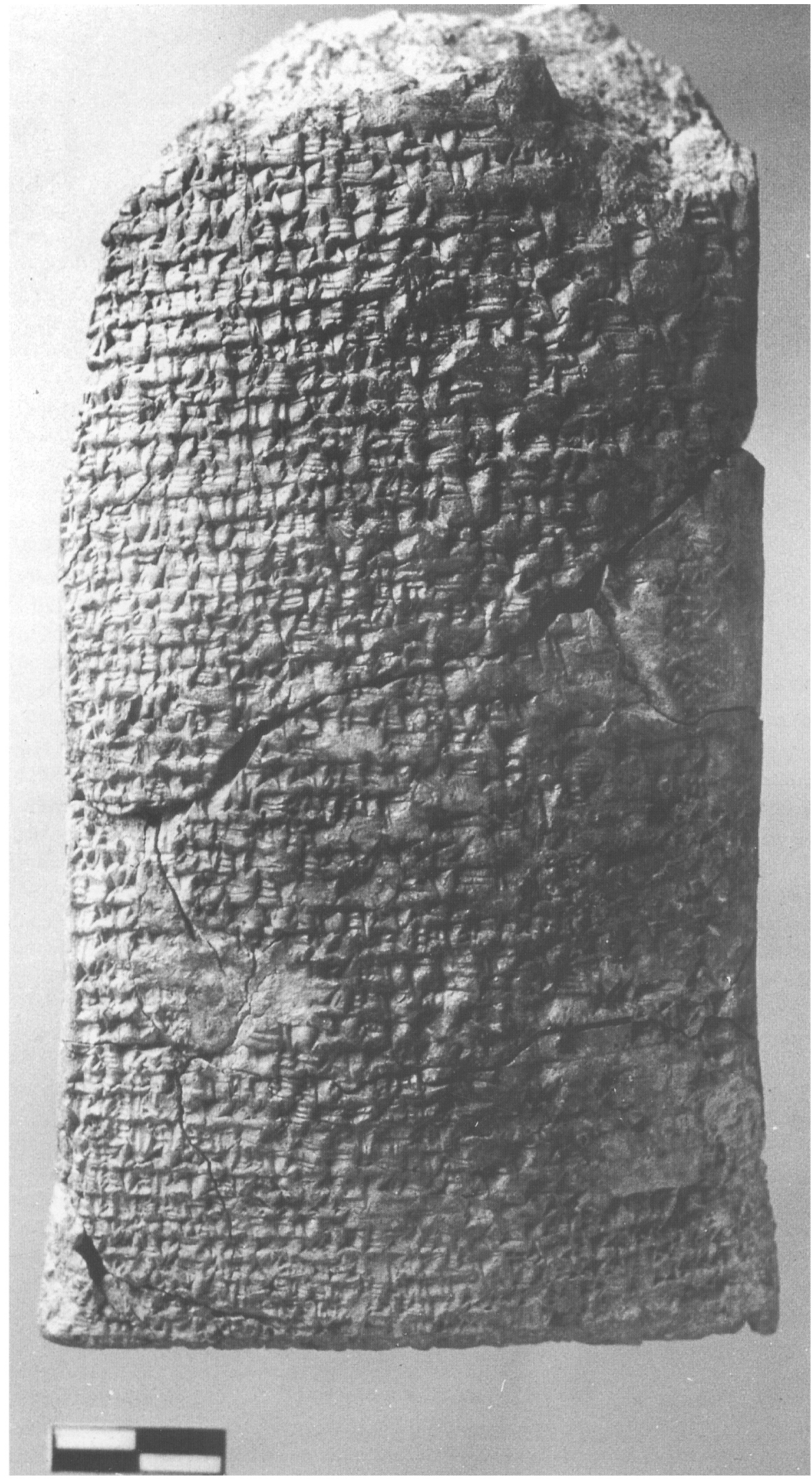

Fig. 4 Sippar Library 1.D.4, reverse: Ludlul I 62-116. 

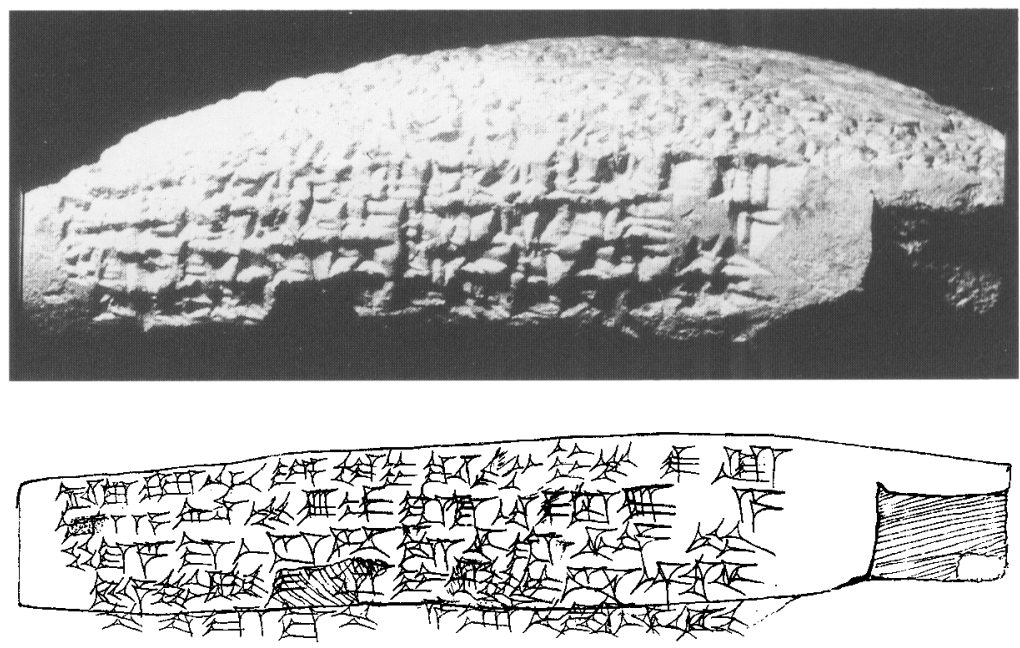

Fig. 5 Sippar Library 1.D.4, top edge: Ludlul I 117-20 and catch-line.

before the tablet was baked but are now lost, and so cannot be read on the photographs, are given in round brackets. Other restorations are made from the duplicates listed in $\mathrm{fn}$. 2 . No collation of the tablet has been possible. Accordingly the copy and edition given here are provisional, in the knowledge that, on occasion, photographs can be surprisingly misleading.

\section{Sippar Library 1.D.4. Copy: Figs. 1-2, 5; photographs: Figs. 3-5}

1 lud-lul be-(lu $\left.u_{4}\right)$ né-me-qi ilu [muš-ta-lum]

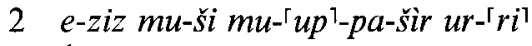

3 d marduk(amar.utu) be-lu $u_{4}$ né-me-qi ilu muš-ta-lum

4 e-ziz mu-ši mu-up-pa-šìr ur-ri

5 šá ki-ma $u_{4}-m u$ me-hुe-e na-mu-ú ug-gat-su

6 ù ki-ma ma-nit še-re-e-ti za-aq-šú ta-a-bi

7 uz-zu-uš-šu la ma-har $a-b u-b u$ ru-'-ub-šú

8 mu-us-sah-hir ka-ra-as-su ka-bat-tuš ta-a-a-rat

9 šá nak-bat qa-ti-šú la i-na-áš-šu-ú šá-ma-'-ú

10 'rit ${ }^{\prime}-t u s ̌ r ~ r a b-b a-a-t i \dot{u}-k a s ̌-s ̌ u ~ m i-i-t i$

$11{ }^{\mathrm{d}}$ marduk(amar.utu) šá nak-bat qa-ti-šủ la i-na-áš-šu-úu šá-ma-['-úu

12 rab-ba-a-ti rit-ta-a-šú ú-kaš-šu mi-i-t[i]

13. šá $i-{ }^{\top} n a^{\top} l i b-\left\ulcorner b a-t i{ }^{\top}-\breve{s u ́}^{\prime}\right.$ up-ta-at-ta-a qab-r[a-a-tum]

$14\left\ulcorner^{i}{ }^{\top}-[n u]-\left\ulcorner\breve{s} u^{\top}\right.\right.$ ina ka-ra-še-e ú-šat-bi ma-[aq-tú]

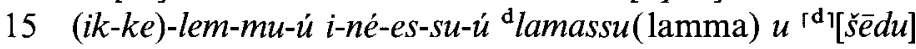

16 (ip-pa)l-la-as-ma a-na šá is-ki-pu-uš il-šú i-sa[h-hur-šú]

17 (ak-sa-a)t a-na sur-ra en-ni-ta-šú ka-bit- ${ }^{-} t i^{1}$

18 [ik]-'ka-riț-ma za-mar $i$-ta-ri a-lit-tuš

19 [i]d-du-ud-ma ri-ma-a-MU (ia 5 ?) ú-kan-na

$20[k] i-{ }^{\circ} i$ a-ra-ah ${ }^{1}$ bu-ri it-ta-na-as-ha-ru arki(egir)-ia

21 [zaq]-「 ta ni'-ta-tu-šu ú-sah-ha-la zu-um-ri

22 [pa-áśs]-rhu sui-in-du-šsu ú-bal-la-tu ${ }^{\mathrm{d}}$ nam-tar

23 [i-qa]b-bi-ma gil-la-ti uš-raš-š́u

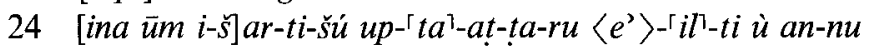

$25\left[\right.$ šu?-ú-m]a ú $-t u k-k u[r] a-^{\prime}-i-b u$ ú-šar-ši

26 [ina te-e-ś] u uš-t[àp-p]a-ru šu-ru-up-pu-ú u hur-ba-šú

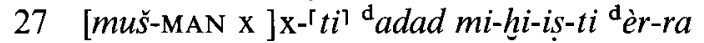

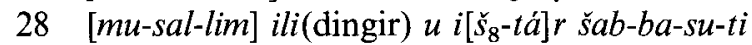

29 [be-lum mi]m-ma ${ }^{\circ l i b-b i}$ ill ${ }^{\text {'meš }} i$-bar-ri 
$30 \quad$ [ma-na-ma ina $\left.i l^{\mathrm{m}}\right]^{\mathrm{es}}$ a-l lak-ta ${ }^{1}-$ sú $^{-}$ul $i-d e$

31 ['marduk mi]m-ma lib-bi ili meš $i$-bar-ri

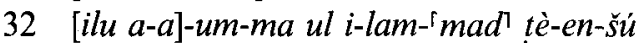

33 [ana ki-i] kab-ta-at 'qāt(šu)-su lib'-ba-š́u re-mi-ni

34 [ana ki-i] gas-șu ${ }^{\text {ggiš }} k a k k a($ tukul )-šủ ka-bat-ta-šú muš-neš-šat

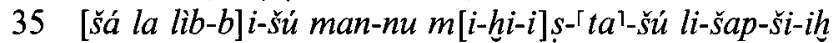

36 [e-la] kab-ta-ti-šú (sup. ras.) a-a-ú li-šá-lil qāt (šsu) ${ }^{\min }{ }_{-s u}$

37 [lu-šá-p]i ug-gat'(GIš)-su šá 'ki'-ma nu-ú-nu a-ku-lu ru-šum-tú

38 [i-nu-na] $m^{2}-m a$ za-mar ki-i ú-bal-li-tu mi-tu-tu

39 [lu-šal-m]id-ma niš̌̀ (ùg) ${ }^{\text {meš }}{ }^{\text {r }}$ qit-ru-ba ${ }^{1}$ gu-ma-al-šin

40 (h) $[i-i s-s a]-a s-{ }^{\top} s u^{\top}$ damiqtu( $\left.\operatorname{sig}_{5}\right)^{t u}\left[{ }^{m} \mathrm{x}\right]-\mathrm{si}^{\mathrm{N}}$-na lit-bal

41 (iš)-[tu] $u_{4}-m i$ be-li i-ni-'nal-an-ni

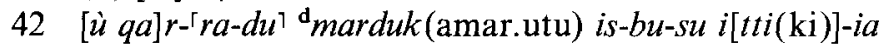

$43[i](d-d a-a) n-n i$ ilì (dingir.mu) šá-da-a-šú $i-l i$

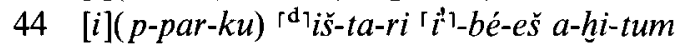

$45\left[\right.$ [is-lit $\left.{ }^{\mathrm{d}} \check{s} \bar{e}\right] d([\mathrm{ala}] \mathrm{d})^{'} d u^{\top}-u n-q u$ śá $i-d i-i a$

$46 \quad[i p-r u-u d l](a-m) a s-s i-m a$ šá-nam-ma ${ }^{\prime} i^{1}-{ }_{-}{ }^{2} e^{\prime}-\dot{u}$

47 [in-né-tir b]a-al-tum du-ú-tu ú-tam-mi[l]

48 [si-im-ti ip-pa-r] i-is-ma ta-ra-niš iš-hi-[it]

49 [iš-šak-na-nim-ma ${ }^{\top} i-d a^{\top}-a-t i$ pi-r $[i t-t i]$

50 [uš-te-și $\langle$ ina $\rangle$ bïti-ia ka-ma-a-t] i a[r-pu-ud]

51-61 broken away

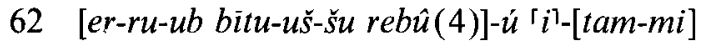

63 [ha-áššš pi-i ha-še]-「e $e^{\urcorner} s[u-b a l-k u t]$

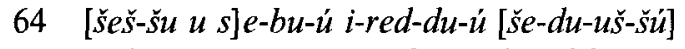

$65[i](k-s u-r) u$-nim-ma ri-kis se-bet il-lat-[su-un]

$66\left(u_{4}\right)-[m] i-i \check{s} l a ~ p a-d u-u ́ u$-tuk-k[iš maš-lu]

67 ' ' $\dot{u}^{\top}$ iš-tén šir (uzu)-šu-nu-ma pa-' i-te-[e]d-du

68 (in)-na-ad-ru-nim-ma na-an-huu-zu i-šá-tís

69 (tušs)-ša ù nap-ra-ku ú-šam-ga-ru eli-ia $a_{5}$

70 (mu)t-tal-lu pi-ia a-pa-tís i-te-eš-'u

71 (ša)p-ta-a-a šá it-ta-aṣ-ba-ra ha-šik-kiš e-mi

72 (šá-p)u-tum ša-gi-ma-tum šá-qu-um-meš ip-pár-šid

73 (ša)-qa-a-tum re-šá-a-a ik-nu-šu qaq-qar-šun

74 (li)b-ba kab-ba-ra-a pi-rit-tum ú-tan-ni-iš

75 (r)a-pa-ášs-tum i-ra-tum a-ga-ášsu-gú it-te-'-e

76 šad-di-ha a-ḩa-a-a ku-te-et-tu-ma i-tah-za

77 šá e-tel-liš at-tal-la-ku ha-la-liš al-ma-「ad'

78 šar-ra-ha-ku-ma a-tur a-na re-e-r ${ }^{-1} i^{1}$

79 a-na rap-ši ki-ma-ti e-te-me e-da-n[iś]

80 su-ú-qu a-ba-a-ma tur-ru-șa ú-ba-na-a- ${ }^{-} i$

81 er-ru-ub ekal(é.gal)-liš-ma i-sa-am-pu-ra $i^{-}{ }^{-} n a^{1}-a-{ }^{\top} t i^{1}$

82 àli(uru) ki-ma a-a-bi né-kel-man-' ni'

83 tu-šá-ma nak-ra-ti na-an-dur-ti ma-a- ${ }^{\Gamma} t i^{1}$

84 a-na $a-[h] i-i$ a-hi $i-t u-\lceil r a\urcorner$

85 a-na lem-nu u gal-le-e i-tu-ra $i b-{ }^{-} r i^{2} 1$

86 'na-al-bu'-bu tap-pu-ú ú-nam-gar-an-「ni'

$87\left\ulcorner^{\lceil} k i^{\top}-n a-a t-t[i]\right.$ a-na na-aq da-mu ú-mar-ra-ás̆ giškakka(tukul)

$88 r u$-' $\grave{u}^{\prime}-a$ ta $a^{\top}-a-b i$ ú-šar-ra-șa na-piš-ti

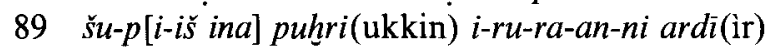

90 amtī (géme) ina 'pa'-an um-ma-ni ta-pil-ti iq-bi

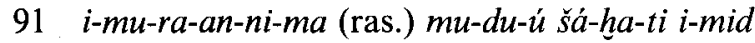

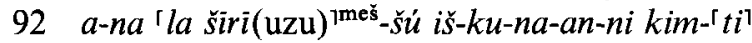

93 a-na qa-Г$a b$ da'-me-eq-ti-ia pe-ta-at-su hă̌-ti 


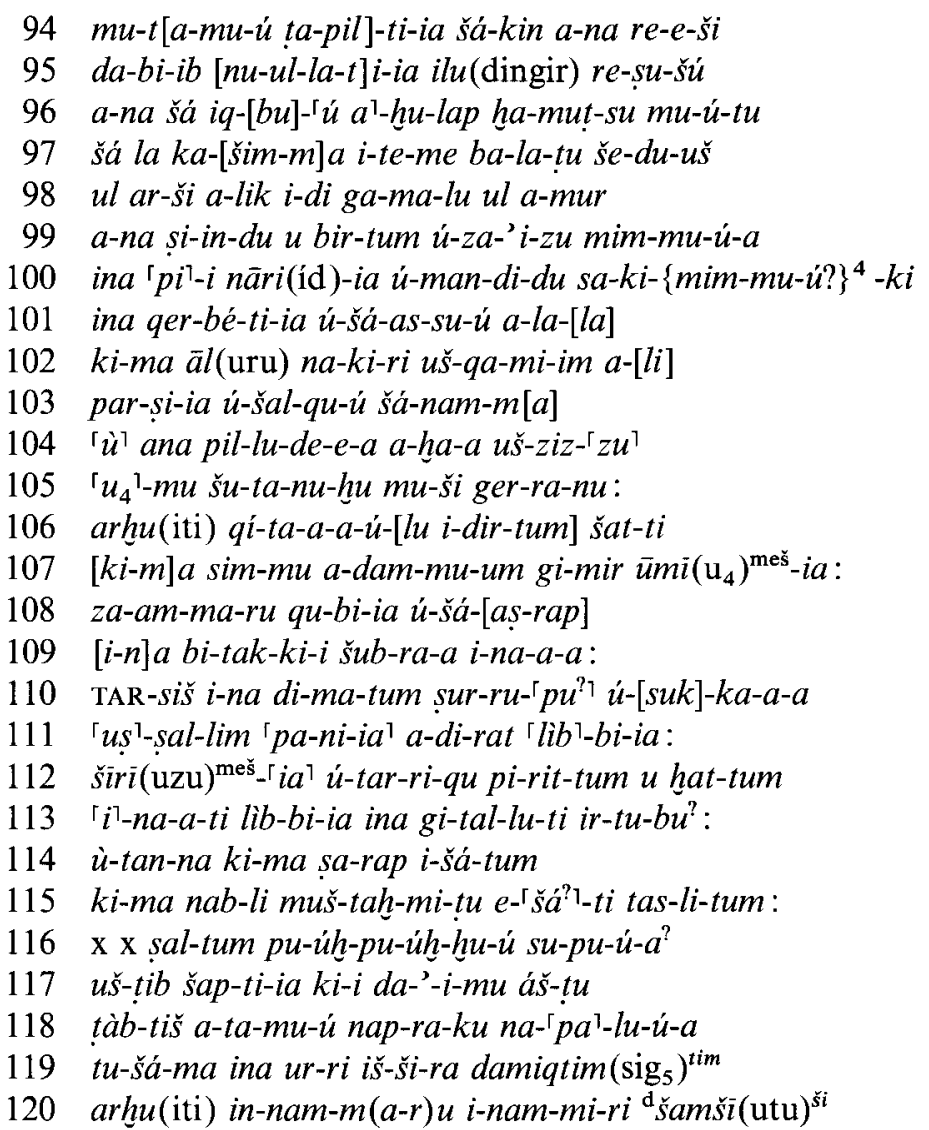

II 1 šat-tam-ma ana b(a-lat a-d)an-nu it ${ }^{2}-t i-i q$

In view of the number of improvements in our understanding of the text yielded by the new readings on the manuscript from Sippar, the whole Tablet is here translated afresh. The division into double couplets or quatrains is modern, of course, but seems to be sustained by the development of the narrative, parallelism and other poetic devices, except in 11.77-88. As the text stands 11. 77-9 form a triplet, $80-3$ a quatrain and $84-8$ a stanza of five lines. The situation can be rescued by assuming that 1.84 has been displaced from between 11.79 and 80 .

1 I will praise the lord of wisdom, the compassionate god,

2 raging at night, relenting by day,

3 Marduk, lord of wisdom, the compassionate god,

4 raging at night, relenting by day!

5 Though his anger is like a violent tempest, a desert waste,

6 he also blows soft like the breeze of the morning;

7 though his rage is undefiable, his fury the Deluge,

8 his mind is merciful, his heart forgiving.

9 Though the full force of his hand the heavens cannot bear,

10 his gentle palm rescues the dying;

$11 \mathrm{O}$ Marduk, the full force of whose hand the heavens cannot bear,

12 his palm is so gentle it rescues the dying.

${ }^{4}$ Apparent dittography from the line above. 
13 Though in his wrath tombs were laid open,

14 he then let the fallen rise from the slaughter.

15 He gives a glare, and protective spirits take leave (of a man),

16 he looks kindly, and the guardian god returns to the one he forsook.

17 His grievous retribution is immediate and terrible,

18 suddenly he relents and becomes like a mother:

19 he hurries to treat his ${ }^{5}$ darling tenderly,

20 like a cow with a calf he keeps following him ${ }^{6}$ around.

21 His floggings have barbs to pierce the body,

22 but his bandages are soft so they revive the dying. ${ }^{7}$

23 By his command he makes one incur sins,

24 on his day of justice sin and guilt are absolved.

25 He it is afflicts one with the demons of sickness,

26 by whose spell are driven off shivers and chills,

27 who ... the downpours of Adad and the ravages of Erra, ${ }^{8}$

28 who makes the angry protective deities friendly.

29 The lord can see all the gods keep in their hearts,

30 but not one of the gods can fathom his ways;

31 Marduk can see all the gods keep in their hearts,

32 but not one god can divine his intentions.

33 As his hand is heavy, so his heart is merciful;

34 as his weapons are savage, so his will is healing.

35 Without his consent who may soothe his blows?

36 without his willing it who may stay ${ }^{9}$ his hand?

37 I, who like a fish ate mud, will vaunt his wrath,

38 quickly he gave me protection, just as he quickened the dead;

39 I will teach the people how near is his mercy,

40 may his favourable grace take away their [sin.]

41 From the day the Lord ordered me punished,

42 and the warrior Marduk became angry with me,

43 my god forsook me and disappeared,

44 my goddess failed me and departed elsewhere.

45 The angel of luck split away from my side,

46 my guardian spirit took fright and sought out another.

47 My vigour took itself off, my manly features became overcast,

48 my rank was cut off, and my protection fled away. ${ }^{10}$

49 Terrifying portents beset me,

50 I was driven from my house and wandered outside.

51 Each day the omens taken for me were confused and contradictory,

52 my course was not determined by consulting diviner and dream-interpreter.

53 What I overheard in the street portended evil,

54 I lay down at night and my dreams were terrifying.

55 The king, the flesh of the gods, the sun of his people,

56 became hard of heart, and changed pardon to malevolence.

\footnotetext{
${ }^{5}$ Sippar: my.

${ }^{6}$ Sippar: me.

7Literally: "Namtar", i.e. the Angel of Death.

${ }^{8}$ I.e. plague.

${ }^{9}$ Nimrud MS: "lighten".
}

\footnotetext{
${ }^{10}$ Sultantepe MS: "flew away". Other MSS: "my rank was cut off and fled by the sun-screen". "Protection" and "sun-screen" both translate Akk. taränu, a structure which kept the sun out of the house, perhaps a temporary roof over the courtyard.
} 
57 The courtiers were scheming how to betray me,

58 gathered into a clique to spread treachery.

59 If one said, "I shall make him spill his life!"

60 a second says, "I ousted him from his post!"

61 Just so the third: "I shall grab his office!"

62 the fourth declared, "I shall take over his estate!"

63 The fifth turns against (me) the opinion of fifty,

64 as the sixth and seventh follow hard on his heels. ${ }^{11}$

65 This gang of seven gathered their forces against me,

66 merciless as demons, the image of devils.

67 One was their flesh, but each had his own voice,

68 they became savage to me, flaring up like fire.

69 Slander and deception they set in alliance against me,

70 my eloquent mouth they took in check as with reins.

71 Though my lips had been so loquacious, I became like a deaf-mute,

72 my sonorous tones disappeared into silence.

73 My head held so high bowed down to the ground,

74 my heart so stout was made feeble by terror.

75 My breast so broad - a youngster pushed it aside,

76 my wide-reaching arms were held tight to my side.

77 I learned to slink by unnoticed, who once went about in lordly style,

78 I who had been so grand turned into a slave.

79 To my numerous family I became a man without kin,

84 my brother became a stranger to me. ${ }^{12}$

80 As I passed down the street fingers were pointed,

81 as I went into the palace eyes were winking.

82 My city glared at me as if an enemy,

83 my country (was) savage as if it were foreign.

85 My friend turned into an ill-wisher, a very demon,

86 in a rage my companion was denouncing me,

87 my fellow soiling a weapon for bloodshed, ${ }^{13}$

88 my best friend tainting my life with slander. ${ }^{14}$

89 My slave cursed me publicly and in company,

90 in front of the crowd my slave-girl reviled me.

91 If an acquaintance saw me he went into hiding,

92 my family treated me as not of their blood.

93 A pit lay open for the man who spoke well of me,

94 he who talked ill of me was given promotion.

95 The one who devised lies about me had his god on his side,

96 to the one who said "Pity on you!" death came swiftly.

97 For him who offered no help life became a very charm,

98 I had no-one to aid me, I was shown no mercy.

99 They distributed my belongings to the mob and the riff-raff,

100 the mouths of my canals they blocked up with silt.

\footnotetext{
${ }^{11}$ Literally: "like his guardian spirit".

${ }^{12}$ As an experiment, we have brought forward this line from its traditional place five lines later in order to maintain the composition's regular succession of quatrains.
}

\footnotetext{
${ }^{13}$ Sultantepe MS (corrupt): "constantly" instead of "for bloodshed".

${ }^{14}$ Sippar (corrupt?): "my best friend making my life a misery".
} 
101 They removed the work-song from my fields,

102 my city fell silent like a city of the enemy.

103 They had someone else take my offices,

104 and appointed a stranger to my posts.

105 The day was sighing, the night lamentation,

106 the month was grief, the year sorrow.

107 All my days I was moaning like a dove, ${ }^{15}$

108 sobbing mournfully like a singer.

109 My eyes were occupied with perpetual weeping,

110 like one cast out my cheeks were hot-stung with tears.

111 The fear in my heart kept clouding my countenance,

112 terror and panic turned pallid my skin.

113 The "eyes" of my heart quaked with constant trembling,

$114 \mathrm{I} /$ they ... like the scorching of fire.

115 Like flickering flame my prayer was confusion,

116 my ... was a fight, a brawl my petition.

117 I sweetened my speech, but it was impenetrable as the dark,

118 I talked sharply, ${ }^{16}$ my conversation was a hindrance.

119 "Surely in the morning good fortune will befall me,

120 the new moon will appear and my sun will shine on me!"

II 1 All that year and into the next the deadline I set went by.

\section{Notes}

1. Although the incipit was, of course, already well known from the colophons of other sources, the Sippar tablet is the first manuscript of Tablet I so far discovered that actually preserves the first word.

2, 4. W. L. Moran's reading of the first word is thus confirmed (JAOS 103 [1983], pp. 255 f.; cf. W. von Soden, TUAT III/1, p. 114), as is the Nimrud tablet's muppašir versus Aššur's mupaššir (see Moran, op. cit.).

5. Nimrud's na-mu-ú (versus la-mu-úu in the Aššur source) is confirmed not only by Sippar, but also by a partly unpublished Kuyunjik manuscript (K 9392, joined to K $9810=$ Lambert, $B W L$ addenda, p. 343).

6. Sippar's še-re-e-t $t$ agrees with K $9392+9810$, against meš-ri-ti/te in the tablets from Nimrud and Aššur. Before condemning the latter as a corruption one should consider whether meš-ri-ta in the lyrical invocation to the rising sun, $B A M 323$ and duplicates (see $C A D \mathrm{M} / 2$, p. 41), is the same word.

9. For the reading nak-bat instead of nag-be (now four manuscripts), against the Kuyunjik manuscript's nag$b i$, see von Soden, TUAT III/1, p. 115.

10 , 12. The plene writing of the second vowel in rab-ba-a-ti (also BM 66345, unpub.) suggests this word is not, as generally supposed, the adjective rabbatu. We take it as the stative rabbat, with its inflected ending taking stress and length on account of the "overhanging" vowel (itself perhaps the legacy of an MB subjunctive, rabbátu: cf. $G A G \S 83 \mathrm{a}$ ). This analysis is supported by the Kuyunjik manuscript, which reads rab-bat (Lambert, BWL, p. 343).

14. The beginning of the line is incomplete on the Sippar manuscript, but in the light of its initial $i$, neither

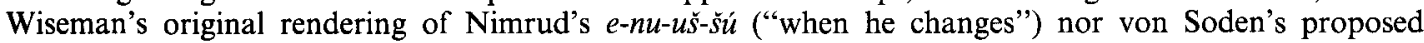

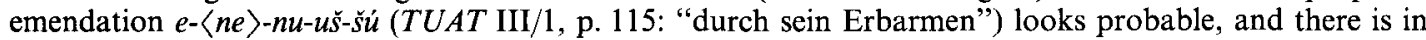
any case clearly no room for enēnuššs. The adverb in̄ušs also appears as enūšsu, and Nimrud's word is probably better understood as a typical late Assyrian orthography, with the stressed syllable marked by closure.

16. Like $C A D \mathrm{~S}$, pp. $70 \mathrm{f}$., we understand $i l s \breve{u}$ to be the subject of isahhuršu, not Marduk (so Wiseman, von Soden, op. cit., and Foster, Muses ${ }^{1}$, p. 310): literally "his god returns to the one he (the personal god) forsook." Foster's revised translation, Muses ${ }^{2}$, p. 308, follows suit. Nimrud must now be read not ' 'u'

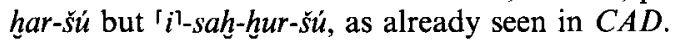

18. According to notes made in Baghdad, Sippar's rendering of the first word is [x]-ka-ab/t-ma,but on the photograph the middle of the third sign is missing and other decipherments are possible. To reconcile this with Nimrud's $i k$-kar-x-ma we propose that a IV/1 present ikkarritma is intended (rather than Wiseman's ikkarrat; a reading $i k$-kar-'rit ${ }^{\top}-m a$ looks good on the photograph of the Nimrud tablet), and that *karătu is therefore $i / i$ class. In the second half of the line Nimrud can now be seen to read $i$-tar. Sippar's spelling

\footnotetext{
${ }^{15}$ Sippar (corrupt?): "carbuncle" instead of "dove". $\quad{ }^{16}$ Literally: "I talked like salt".
} 
$i-t a-r i$ is also found on the unpublished source BM 66345; for itâr so written see, e.g., Lambert, $B W L$, p. 108, 6: $i$-ta-ri a-na ti-it-ti (Counsels of a Pessimist, Kuyunjik manuscript). This orthography is in accordance with the findings of a recent study of NB grammar, that in the I/ 1 present of the middle weak verb "there is a tendency, slightly marked in II $\bar{i}$ verbs ( 23 per cent of cases), but strongly marked in II $\bar{u}$ verbs ( 72 per cent), to add an unjustified final vowel" (N. R. Woodington, "A Grammar of the NeoBabylonian Letters of the Kuyunjik Collection", Yale Ph.D. 1982 [Ann Arbor, 1984], pp. 132 f., with further examples). We take alittuš as a late form of locative-terminative älittišs (cf. ìteme šéduš in 1. 97).

19-20. The new manuscript has arkiya for arkišu in 1. 20, thus turning the image into one particular to the narrator's own recent experience of Marduk's loving care. Though in our view this gives less satisfactory sense, it does suggest that $r i-m a-a$-MU in 1. 19, contrasting with Nimrud's ri-ma-šu (Wiseman's copy is confirmed as accurate by photograph), also substitutes a first-person suffix for a third. If so, we are dealing with a noun in the accusative, either a hitherto unknown word from $\sqrt{ } \mathrm{rm}$ ' (i.e., *ri/emû or ${ }^{*} r i m u$ ) or, displaying a (stressed?) anaptyctic vowel as found in texts which use "hymno-epic" style, rimu from $\sqrt{ }{ }^{\prime} m$. The latter is chosen here, since it is such a fitting object of kunnu and suits the mood of motherly attention that pervades the couplet.

25. Sippar shows that Nimrud's apparent $\mathrm{x}-t u k-k a$ ŠA-i-ba (so the copy and photograph) is presumably a poorly written $\dot{u}-t u k-k a r a-i-b a$. As a demon who brings sickness the $u t u k k u$ is well known, but note also ${ }^{\mathrm{d}}{ }{ }^{\prime}{ }^{\prime}-i-b i$ as the agent of disease in Sakikku XVII (R. Labat, TDP, p. 162, 59=Pl. 42, 57'). Elsewhere $r a^{\prime} i b u$ is a common noun for some kind of sickness, no doubt characterized by physical shivering $\left(r a^{\prime} \bar{a} b u\right)$.

26. Sippar disposes of Wiseman's unconvincing ip-pa-ru; Nimrud's KU่ IB are a poorly written uš-tàp(photograph).

27. The participle at the beginning of this line, preserved only in Nimrud, continues to give difficulties (Wiseman, AnSt 30, p. 105: muš-man-ti rihisti, "who reduces the storm"; Foster, RA 75 [1981 ], p. 189:

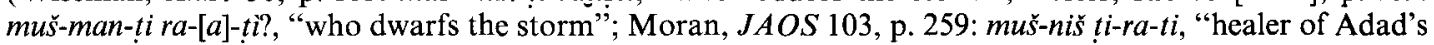
strokes"; R. Albertz, Festschrift Deller [AOAT 220], p. 29: "der die Hiebe Adads heilt"; von Soden, TUAT III/1, p. 116: muš-par'-kit' rihisti, "der aufhören läßt die Überschwemmung"; Foster, Muses ${ }^{1}$, p. 311: "who raises the flood"). The newly available photograph confirms Wiseman's copy. What precedes dadad in Sippar, however, is not easily rihisti, and a convincing decipherment eludes us.

29 and 31. In Nimrud the signs that precede lib-bi, read by Wiseman as 'at-ta sa ina?', now need collation: the sign AD is perhaps mim!-ma. There is no room in Sippar for what follows, which seems to be witness to a more prolix expression, e.g. mimma mala libbi ili ?

30. The only witness to the beginning of the line is Nimrud. The photograph now discounts the reading $m a-$ te-ma put forward by Moran, op. cit; also Albertz, Fs Deller, p. $30^{26}$. We restore Sippar's ina $\left.i l^{\mathrm{m}}\right]^{\mathrm{es}}$ in agreement with the trace of ME]š on the Kuyunjik manuscript, 79-7-8, 225.

36. Sippar reads li-šá-lil for Nimrud's li-qal-lil. We prefer this, as the lectio difficilior, and take it as lišălil, literally "who may cause his hand to hang?", i.e., make it stop in mid-air before it delivers the blow.

37. Nimrud has perhaps the present, $a k-k[a-l u \ldots .$.

38. Now that the line is complete the derivation of $i$-nu-nam-ma from enēnu, "to punish", no longer seems possible. Besides, this verb seems to be $i / i$ class only (contra CAD E, p. 164), and the dative suffix was not suitable (ininanni is expected: see 1. 41). Accordingly we follow von Soden (TUAT III/1, p. 117: "er erwies mir alsbald Freundlichkeit"), and analyse it as from enēenu (a/u), "to show special favour", in the sense found in personal names of the type Inun-DN, which acknowledges the deity's protection of the helpless newborn.

39. The word gumälu is new. Nimrud offers, as a variant, the common noun gi-[mil-šin] (so the photograph).

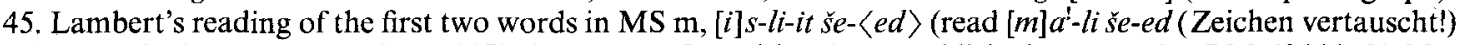
by von Soden, TUAT III/1, p. 117), is now confirmed by the unpublished manuscript BM $68444,8^{\prime}:[i] s$ lit $[\check{S}] e-e-d u$ dum-qí.

48. Sippar's tarāniš can now be seen to be shared by Lambert's MS k, i 1': ... ]-'niš iš-hii-it ${ }^{1}$ (from Babylon, $B W L$, Pl. 4); the two other manuscripts preserved at this point have ta-ra-na (Sultantepe) and ta-ra-ni (Kuyunjik). The alternation of tarāna/i and tarāniš perhaps derives by false analogy from the adverbial endings -āniš and -āni (in adverbs of comparison: W. Farber, "Altbabylonische Adverbialendungen auf -āni", Kraus $A V$, pp. 37-47; in an adverb of direction: ú-še-si-a-ši a-pa-ni, YOS XI 19, 13, OB incantation; cf. SB apāniš halälu/aṣ̂u ).

51. The translation of $n u-u p-p u-h u$ (for nuppuhā) as "contradictory" develops the suggestion of von Soden, op. cit., that the word "könnte hier von dem in Omendeutungen häufigen niphu 'Streit' denominiert sein." On this noun see $C A D \mathrm{~N} / 2$, p. 245: "in later extispicy texts, niphu and niphatu are specialized terms for ominous features that turn a prediction into its opposite; however, in earlier texts, niphu seems to indicate a false prediction made by the diviner." Whether contrary or false, it seems safe to infer that nuppuha is a rough synonym of dalh $\bar{a}$. In extispicy, omens that contradict each other mean that an unequivocal answer, yes or no, cannot be obtained, leaving the subject in the dilemma of not knowing how to proceed for the best. In addition to the passage quoted by Lambert in his commentary $(B W L$, p. 284), J. Nougayrol has called attention to the similar phrasing used by the suffering poet of the hymn to Marduk from Ugarit, who encounters the same difficulty: 
dal-ḩat-e-re-tum (=dalhā tērētu) šu-ta-bu-lu $u_{4} \check{s i}$-ru $m u-u \check{s}-s ̌ a-a k-k u$ ša-ilu lúbārû(hal) pu-ha-di ig-dam-ru

Ugaritica V, No. $162,5^{\prime}-7$ '; cf. p. 270

The oracles were confused, the omens debatable,

the dream-interpreter ran out of incense, the diviner out of lambs.

52. The line develops the idea put forward in the preceding one: the soothsayers are unable to give the sufferer the divine guidance he requires to decide (parāsu) his future course of action (alaktu). Our translation follows von Soden, op. cit. ("bei Opferschauer und Traumdeuter blieb mein Weg ungeklärt"), against Lambert's very different rendering (see his remarks in $B W L$, p. 284; also Foster, Muses $^{1}$, p. 312). A third interpretation is $C A D$ 's "I go without ceasing to the bārû or the $\bar{s} \bar{a}$ 'ilu," ( $\breve{\mathbf{S}} / 1$, p. 111 ; similarly A/1, p. 299), which renders the phrase alaktu parsat according to its common usage, though, as Lambert noted, itti is awkward. For Lambert this common usage made it "doubtful if it could be used in a totally different sense," but poets do on occasion surprise their audiences by finding new meaning in an old cliché. As it is understood here the phrase alakti ul parsat is the equivalent of the standard arkati ul ipparras (cf. now Foster's revised translation, "my course was undecided", Muses ${ }^{2}$, p. 310).

56. The unpublished exercise tablet BM 93079 reads the end of the line pa-ta-ri uš-lem-GIš, the last word evidently a mistake for $u s ̌-l e m-m i n$ (so now MS $m$ from Sultantepe). In this connection note that the exercise tablet's error may be more than simple: the signs GIš and MIN share a phonetic value, being nís and $n i$ š respectively.

57. Against $A H w$, taslitu, "etwa 'abwertende Rede'," we read teslitu, connecting it with selû, "to be dishonest, cheat". Note especially $M a l k u$ VIII 35: $m u$-sal-lu-u=sa-ar-ru, "villain" (CT 18 31, obv. 19 // STT 394, i 34).

63. This obscure line, left for the most part untranslated by Lambert (also R. D. Biggs, $A N E T^{3}$, p. $596 ; C A D$ $\mathrm{N} / 1$, p. 19), has elicited widely differing translations: "as the fifth fills his lungs" (Foster, JAOS 103 [1983], p. 128, drawing attention to the pun haššu/hašê ), later rendered "as the fifth pants (to speak)" (Muses", p. 312); "der Thymian-Mund ist verwandelt" (von Soden, TUAT III/1, p. 118). However, there is an idiom pî.. šubalkutu, "to alter someone's opinion", documented by $C A D \mathrm{~N} / 1, \mathrm{p}$. 19 . Here, as elsewhere, šubalkut has negative overtones, with the meaning "changed for the bad", i.e., turned from friendly to hostile. Compare in this regard the omen apodosis Izbu VI 56: tibût(zi) ${ }^{\text {ut }}$ sàr hammă’i(IM.GI) pí-i māt(kur) sarri (lugal) $i b-b a-l a-k a-a t$, "uprising of a rebel king: the king's country will change allegiance" (Leichty, TCS IV, p. 90; also p. 161, XVI 27'; cf. KAR 152, obv. 23; Boissier, DA, p. 219, 10; etc.). This observation provoked Foster's latest, and undoubtedly correct, translation, "as the fifth subverts the mind of fifty" (Muses ${ }^{2}$, p. 310).

64. The word šeduššu is rendered "in his train" by Foster (Muses", p. 312), "seiner Zielsetzung" by von Soden (op. cit., with the note that "das Wort ist wohl mit še du 'Schutzgeist' nicht identisch"). As Foster saw, the point must be that the sixth and seventh follow on the coat-tails of the fifth, i.e., back him up by acting in the same way. As we see it, this is another case of locative $-u(m)$ with comparative force (cf. zammāru in 1. 108), or of -uš for comparative -iš (cf. šêduš in 1.97 and malkatuš, "like a queen", in W. G. Lambert, Kraus $A V$, p. 200 , Hymn to the Queen of Nippur IV 5, as analysed by B. R. M. Groneberg, Syntax, Morphologie und Stil der jungbabylonischen, hymnischen “ Literatur 2 [FAOS 14/2; Stuttgart, 1987], p. 55). Either way, the two conspirators cleave to their fellow as closely as his šedu.

66. Sippar confirms the need to emend MS $m$ to $u-t u k-k i \check{s}$, as already seen by W. L. Moran (in Foster, Muses $^{1}$, p. 325) and von Soden, TUAT III/1, p. 118.

67. Or "Like one ...", reading $[k i-m] a$ : cf. von Soden, op. cit., "ergänze $[k i]$ "." Such a restoration would also fit the space available in Lambert's MS O $(B W L, \mathrm{Pl} .3)$, but on MS m, as copied by Gurney (ibid., $\mathrm{Pl} .1=$ $S T T$ 32), there is much less space, not enough even for $[k i]$ or [gim]. Sippar offers slight variants for the problematical second half of the line (MS m: $\left.p a-a i^{-}{ }^{1} t e^{1}-e d-d i\right)$, which Lambert translated as "united in purpose" (IV/3 stative of wedî; the same translation was put forward by Biggs, $A N E T^{3}$, p. 596, and Foster, Muses $^{1}$, p. 312); von Soden, op. cit., points out that the verb can be read $i$-te-et-ti, "würde immer wieder dunkel", but views the phrase as obscure. Sippar's $p a^{-'}$ is a most unusual orthography of $p \hat{a}$, but there seems no alternative decipherment. The writing $i-t e-[e] d-d u$ in the same manuscript could well stand for iteddi, exhibiting an unsurprising LB indifference to the final vowel, but might alternatively be the $\mathrm{I} / 3$ stative of nadu, i.e. a variation on itaddu, and that is how we take it (note that MS $\mathrm{m}$, like other Sultantepe tablets, is not consistent in showing vocalic endings that are correct by MB standards, e.g. $n u-u p-p u-h u$ for nuppuha in 1.51 ). The phrase pâ itaddu literally means "each was equipped with a mouth," and the line thus states that though the clique of the sufferer's enemies were of like attitude and intent ("one is their flesh"), they were the more deadly for being furnished with seven mouths to spread their different lies against him. Foster now agrees: "one is their body, (but seven) their mouths" (Muses", p. 310).

68. At this and adjacent lines a part of the left edge of the tablet was lost during baking, and cannot be seen on the photograph. However, a transliteration of the line made in 1989 shows that the initial in was still legible on the Sippar tablet at that time. Collation of the other witness to this sign, Lambert's MS O, revealed that there is a trace of the tail of a horizontal wedge above the three vertical wedges with which the sign in question terminates, and $[i] n$ seems to us the most likely decipherment there also, confirming von Soden's reading, op. cit, against $C A D \mathrm{~N} / 1$, p. 60 .

70. For pû muttallu, literally "noble mouth", as an attribute of eloquent authority, note the use of muttallu 
in conjunction with the word apkallu in exorcistic prayers (see the references collected in $C A D \mathrm{M} / 2$, s.v.). As an epithet of gods muttallu occurs particularly often - though not exclusively - with those whose powers rely on a special skill with the spoken word: sages (Ea, Marduk), judges (Šamaš) and viziers (Nabû and Nuska; also Lamma-kakka, constable of E-kur, but cf. Kakka, vizier of Anu). That the sufferer's enemies should have gained control of his "eloquent mouth" fits the sense of the passage well, for evidently they made it impossible for him to defend himself against their lies: his words of defence were not simply ineffective in the face of their slander but, as 1.71 reveals, his eloquence was magically taken away from him.

72. Note the new variant, rimmāti for $\breve{s}$ agimāti, in the previously unavailable piece of the Nippur tablet (CTN IV 201, 72: ' rim $\left.^{\prime}-m a-t i\right)$. The verb in MS m now needs collation: [i]p-par!?-[šid]?

73. As a late variation on the adverb qaqqaršum, the form qaq-qar-šun is also found in a fire incantation (W. G. Lambert, AfO 23 [1970], p. 43, 32); a parallel, K 6057, quoted by $C A D$ Q, p. 124, writes qaq-qar$\check{s} u-u n^{u m}$, an orthography that passes on both variations at once.

76. Sippar's kutettumā is evidently a MB form, showing /e/for /a/despite the lack of a vowel /i/in the third syllable. With regard to this word, only MS m, ki-ta-at-ta, disagrees incontrovertibly with Sippar: other sources appear to have either kutettumā or the more expected SB variant kutattumā (MS O: $k[u-;$ MS n: $k u-t[a-;$ MS X: $k u]-t a-a t-t[u-m a]$ : all Lambert, $B W L, \mathrm{Pl} .3)$. This word is clearly superior to the emended reading kilatta, which must now be discarded. The second half of the line thus translates literally as "they were kept continually covered (with clothing), they held each other." The image of the arms clasped together, tight to the body under the garment, vividly conveys the hunched and cowering figure that the sufferer has become. The gestures described here contrast his former position with his current situation: once a man of expansive action, now has no power.

77. For another example of the contrast between atalluku and halälu see the ritual BM 41577, iv 7' (edited by George, "Four temple rituals", in press).

80. Sippar confirms the emendation of MS m proposed by Lambert, $B W L$, p. 286.

87. Note that ana na-aq da-mu in Sippar stands for kak-dà-a in the Sultantepe source (MS m). The only other manuscript preserved at this point in the line is the commentary (MS G), which can now be read

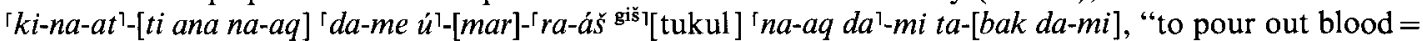
to spill blood" ( $\left.B W L, \mathrm{Pl} .15,17^{\prime}-18^{\prime}\right)$. Read so it confirms kakdâ as a feeble corruption. The reading umarraš was the suggestion of K. Deller, $A f O 20$ (1963), p. 166 (now also $A H w$, s.v. warăšu D).

88. The verb in the Sultantepe manuscript is now to be read $\dot{u}$-kar-r $[a-s] a$, with the exercise tablet published by E. Leichty, Finkelstein Mem. Vol., p. 145 (BM 61433, 8; from Sippar or Babylon). The new tablet disagrees here, but its substitute, $\dot{u}-\breve{s} / s a r-r a-s / z a$, is difficult to parse. The verb $\breve{s a r a ̄ s u}(C A D$ s.v. "to clutch, clasp(?)"; $A H w$, "sich ankrallen"?), attested only in lexical lists, does not offer much hope, and there are as yet no verbs known from $\sqrt{ }$ 'rs $/ z$ or $\sqrt{ } w r s / z$. Rather than reject the new variant as meaningless, however, we assume it to be an unique, "hypercorrect" writing for ušamrșa, reversely analogous with the development inamsar <inasssar, etc. If so, it is of course false -- a development $/ \mathrm{mr} />/ \mathrm{rr} /$ is not observed in Akkadian -perhaps a contrived attempt to solve a failure to read or hear the text properly, and certainly less acceptable than ukarrasa.

97. In taking $\check{s} \bar{e} d u s ̌$ for comparative $\check{s} \bar{e} d i \check{s}$ we follow Moran (JAOS 103, p. 258: "the one against help - his life became life-force itself") and Foster (Muses", p. 313: "the one of no help, his life became charmed"); iteme balātu še $\bar{e}$ sus then means literally "life became like (that of ) a guardian spirit." Others place a different emphasis on the line, and take ša la kâšimma from kâšs A, "to be late" (Deller, AfO 20, p. 167; AHw, p. 463; $C A D \mathrm{~K}$, p. 295; Biggs, $A N E T^{3}$, p. 597; von Soden, $T U A T$ III/1, p. 119). Note that only the Nimrud tablet reads $b a$-lat-su; three manuscripts are now preserved which omit the possessive suffix (MS m: $\mathrm{ti} .1 \mathrm{a}$; Sippar: ba-la-tu; 79-7-8, 225, rev. 1': ba-la-t[u).

107. Sippar has sim-mu where the two other witnesses read su-um-me (MS n from Aššur) and su-um-mi (Nimrud). No doubt groaning was the lot of one suffering from simmu, an especially painful skin condition, but summu is more probably the original word, since the simile "like a dove" is so standard with damāmu (see CAD s.vv. summatu, summiš, summu).

108. Sippar has the same writing of the first word as that found in another late manuscript, still unpublished, cited by W. G. Lambert, JNES 12 (1967), p. 104. For the comparative force of locative $-u(m)$ see idem, Or NS 38 (1969), p. 536, quoting this line; also 1.64 above. The singer in question is a singer of laments.

110. The reading of the first word is problematic; alternative decipherments such as hassiš, "like lettuce", and haššiš, "for a fifth time", are not obviously better. The verb daräsu and the adjective darsu, literally "downtrodden", carry implications of "oust(ed)" from home or "supplant(ed)" in office. These are exactly the fates of the poet of Ludlul. The adjective is also written with initial /t/ in a NA royal ritual $(K A R 137$, ii 4: $i l a ̄ n i^{\text {meš }}$ TAR-su-te, "deposed gods"; cf. ilāni ${ }^{\text {meš }}$ dar-su-ti in the tākultu-ritual Menzel, Tempel II 54, i $30-1)$.

112. Sippar's širiya is a new variant. Nimrud reads maš-ki-ia.

113. The phrase $i-n a-a-t i$ lib-bi-ia looks clear. The "eyes" of the heart can only be its four ventricles. This figurative usage of inu may allude to the fact that the ventricle, like the eye-socket, is a hollow chamber (cf. in $u=$ "bubble"?), but also to its function as the source which supplies blood to the arteries; cf. inu in its meaning "spring", "(river) source". 
114. Nimrud may or may not have agreed with Sippar: all that is left of the line's first word there is an enclitic, ]-ma.

115-18. The sense of these two couplets at last becomes apparent. The sufferer is no longer smoothly articulate, so that his prayers are all tangled confusion, like flame in a fire (115) or a street brawl (116). His words are unintelligible (117), so that the manner of his speech works against his interest (118). The contrast between sweet and sour, $u s ̌ t i b$ and tabtišs, is highlighted by the alliteration.

117. Literally: "I sweetened my lips, they were as difficult (to fathom) as the dark" (Nimrud has, correctly, $a ́ s ̌-t a)$. The idiom of "sweet lips" for euphony of speech is also known from an OB letter (CT $2911, \mathrm{BM}$ 80723, 13: ša-ap-ta-ka lu-ú tà-ba, meaning "speak sweetly"). The clause $k i d a-i-m i$ aštā, as Nimrud wrote it, has been translated as "stiff like a spear(?)" (Wiseman), and "wie eine Lanze schroff" (von Soden). We agree with Foster, Muses", p. 313 ("senseless, like a moron's") that da'imu, "spear" — the only possibility according to the dictionaries — is best rejected in this context. Instead we propose a *paris formation from the root which already yields $d a^{\prime} \bar{a} m u$, "to become dark", da' ummatu, "gloom", etc. With regard to language and speech aštu means difficult to understand, as Foster saw (cf. the famous phrase of Aššurbanipal, Streck, $A s b$., p. 256, 17: $a k-k a-d u-u$ ana $\check{s} u$-te-šu-ri áš-tu, "Akkadian difficult to get straight"; and Ludlul III, MS q 24: pi-iá šá uk-ta-at-ti-mu sa-ba-riš áš-[tu], "my mouth, which had been gagged so that I could not speak clearly").

119. If Nimrud agrees with Sippar the first sign is particularly poorly written: $t u-\breve{s} a$-ma (see the photograph).

119-20. It is now clear that the sufferer sets himself a deadline: if he can survive to the next new moon his plight will surely be improved. This couplet explains what is meant by adanni (so the Nimrud manuscript) in the catch-line. However, the year passed into the next, and the new moon still did not bring him the relief he anticipated.

\section{The Šamaš Hymn}

The remains of the reverse of a tablet in four columns, two each side, is all that is left of the Sippar library's copy of the great Šmaš Hymn edited by Lambert in Babylonian Wisdom Literature, pp. 121-38. The new piece, which comes from Niche 2 B, provides a further source for 11. 130-57 (col. iii) and 183-end (col. iv). A short colophon is appended. The fragment has little to add to the text already known, and is given here without translation. A curiosity of the piece is that the margin between columns iii and iv harbours clusters of signs which presumably provide additional text or glosses. Unfortunately we are unable, for the moment, to decipher them.

The copy was made from a pair of photographs taken in Baghdad. A future collation of the tablet in Baghdad should allow decipherment of those signs which we have not been able to read satisfactorily from the photographs. This is particularly the case in column iv, where the tablet as photographed is still quite dirty. Our inability to make out all the signs preserved in these lines is regrettable, since it is exactly here, $11.182 \mathrm{ff}$., that the published edition is in need of a new witness.

IM 124633 (Sippar Excavation No. 2329, Season No. 8/166). Copy: Fig. 6; photograph: Fig. 7

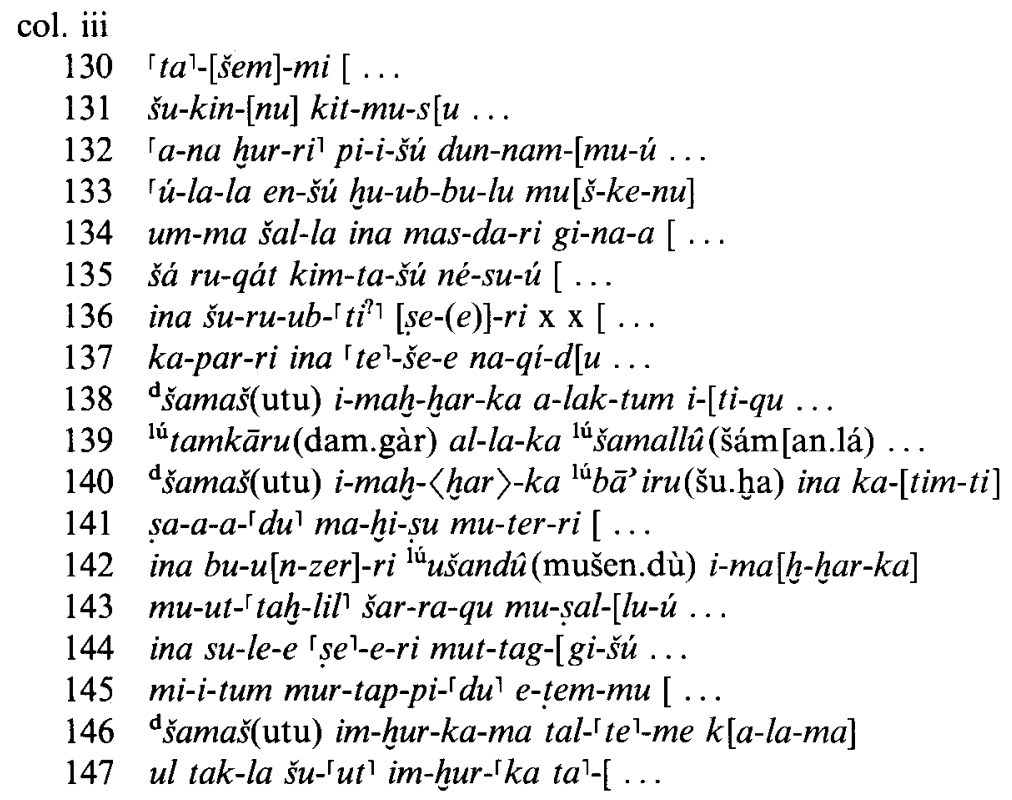




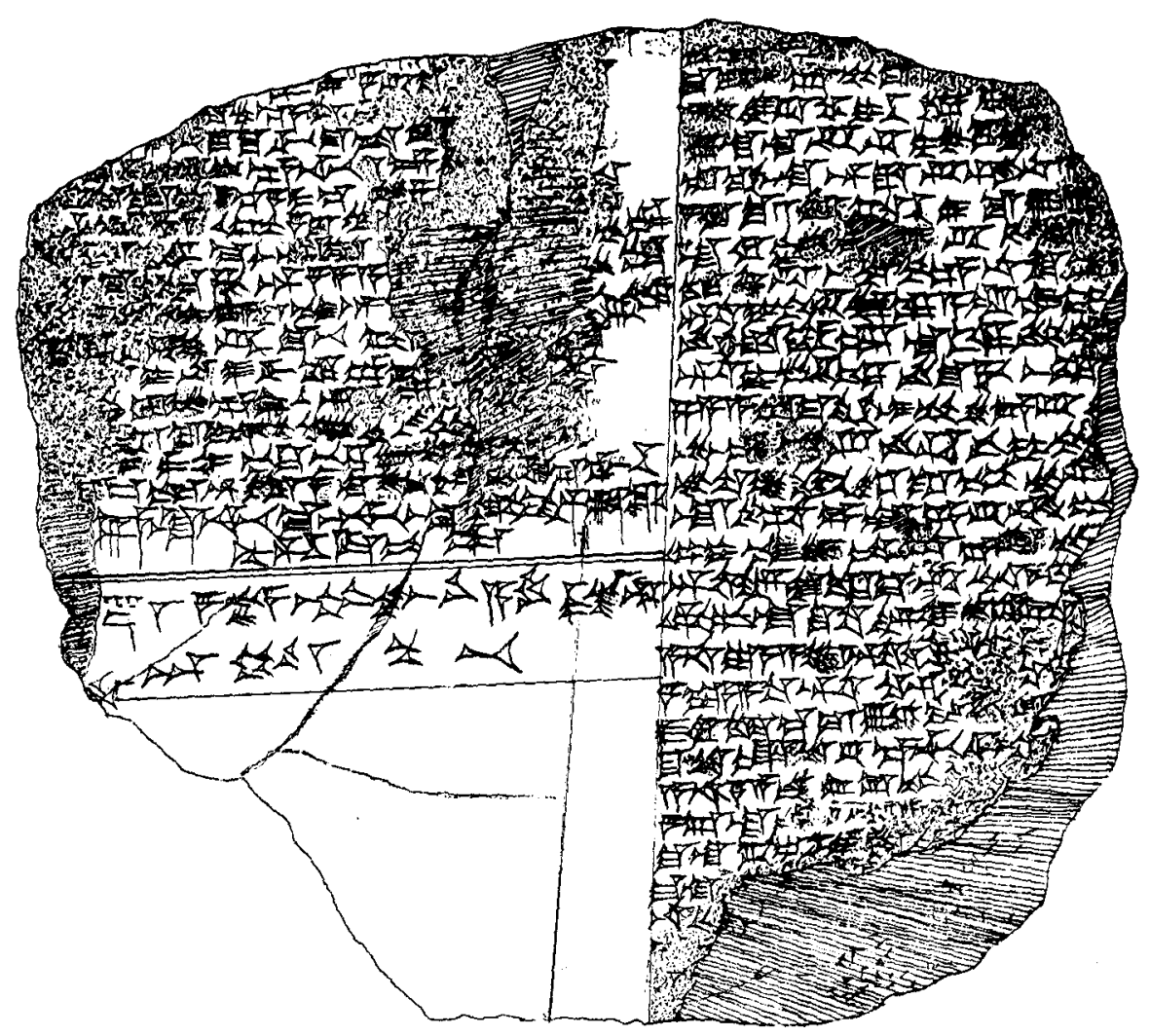

Fig. 6 IM 124633: Šamaš Hymn 130-57, 183-201.

$148 \quad a-n a i a-a-r u^{1}{ }^{\mathrm{d}} \check{s} a m a s ̌(u t u) \times(\ldots$

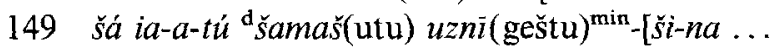

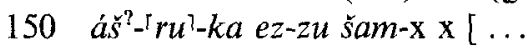

151 「tušste $e^{\top}$-šèr te-re-e-ti-ši-[na ...

152 a-na šá-a-ár er-bet-tim [...

153 šá kal-la x $\times[\ldots$

154 ma-la ga-ap-pi ${ }^{\mathrm{r}} n i^{?}{ }^{2}-[t i-i l \ldots$

155 ma-la $[.$.

156 ina ud.20. $[\mathrm{kam} . .$.

$157 \times[\ldots$

col. iv

183

184

185

186

187

188

190

191

192

193

194

$195 \mathrm{f}$.

197

198
... $]$ traces $[\ldots$

... ] ${ }^{\top} p a-n i^{\top} \breve{s} a^{\top}-{ }^{\top} r i^{1}-[k u \ldots$

...t]e-še-e ${ }^{r} q a^{?}-[$ bal ...

...mit]-lu-ku ši-tul-ta $m[i l-k u]$

$\ldots] \times \times \times x \times-e-t i{ }^{\top}$ ana ${ }^{\top}$ niši $\left(\right.$ ùg) $\left[\left[^{\text {meš }} \ldots\right.\right.$

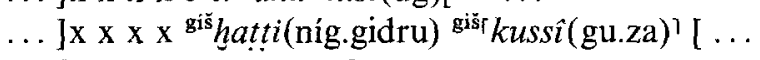

... ]x x-im-ma ina $\mathrm{x} \times[\ldots$

... ]x $n e^{?} h a^{?}$ AN $\check{s} a ́ a-a-[b i ? \ldots$

$\ldots] \times$ x $x$ x x x-tum AN $[\ldots$

[ana é.babbar.ra biti] nam-ri šu-bat ta-[ši-la-ti-ka]

... ]X $i-n a-a ́ a ̆ s-s i-r k a^{7}$ nap-t $[a-a n-k i b-r a-t] i$

[šarru(lugal) šak]-kan-gu? e-ni u rubû(nun) 'bilat (gú.un?)'-[su-nu lišs-šu-ka?] Ø?

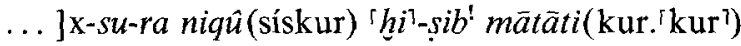

$\ldots\}$ x pa-rak-ka-ka ${ }^{\mathrm{x}} \mathrm{x} \times \mathrm{x}^{1}$ 


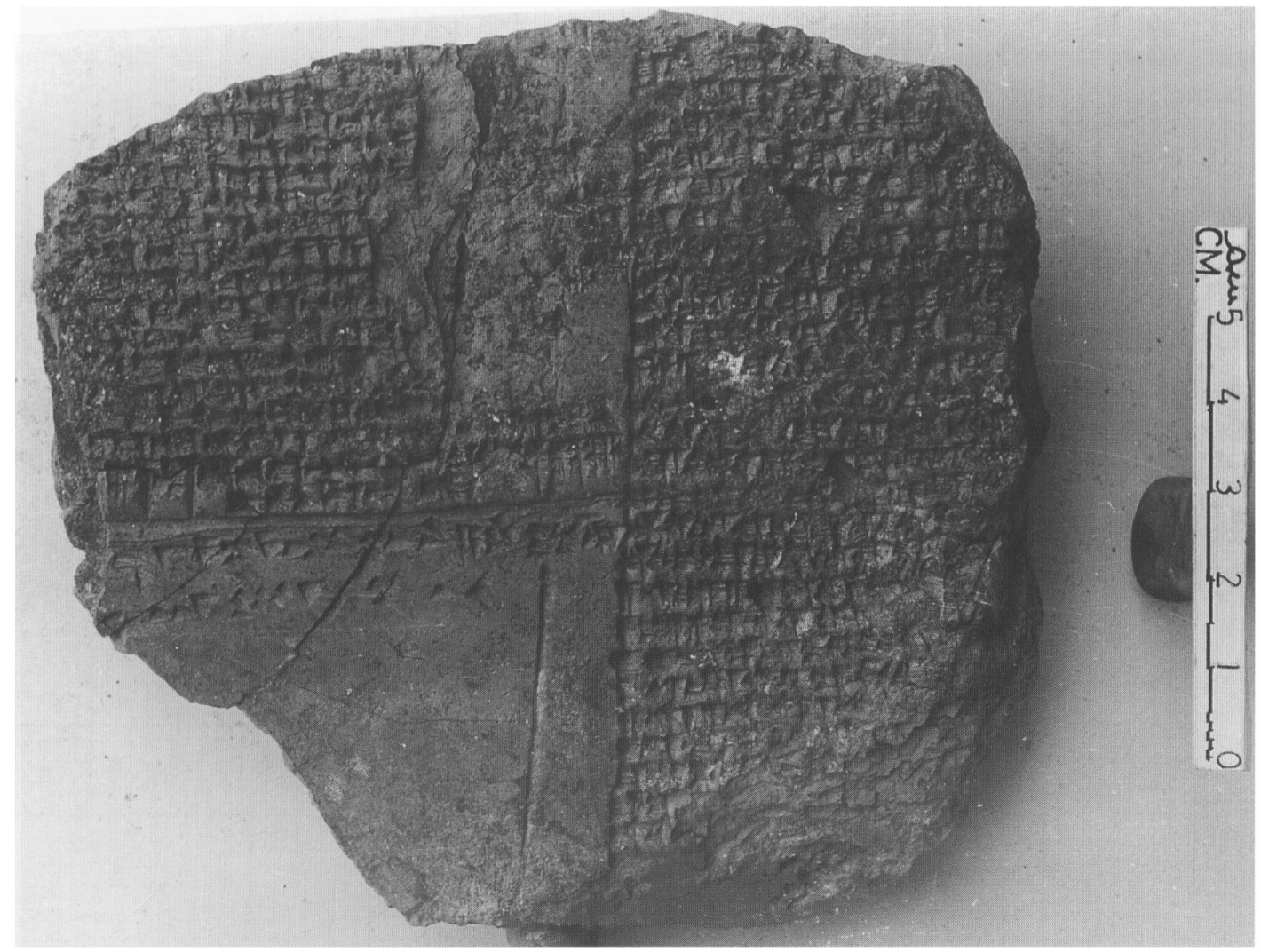

Fig. 7 IM 124633: Šamaš Hymn 130-57, 183-201.

$200 \quad$ [a-a] kal-la-ti rabiti(gal $)^{t i}$ ina bit(é) erši (ki.ná)

201 [si-lim?] nu-hu liq-bi-ka

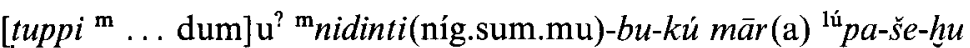
$\left[q \bar{a} t^{\mathrm{m}} \ldots\right] \mathrm{x}{ }^{\mathrm{d}}{ }^{\mathrm{d}}$ marduk(amar.utu) úl qati(til)

The text differs materially from Lambert's in the following lines: 136: the last two signs cannot be reconciled with the expected $r \vec{e} \hat{u} ; 140$ : ina is inserted into b $\vec{a}^{\prime}$ ir katimti (cf. the parallel in 142); 149: $y \bar{a} t u$ erroneously replaces $a d n \bar{a} t i$ by dittography from the line above; 150 : to our eyes the first sign is neither pa or maš; 153: insertion of $\check{s} a$ before kal; the signs that follow kal do not appear

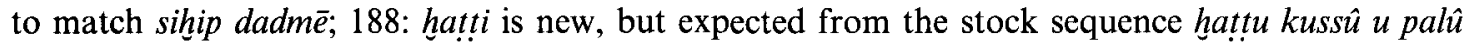
(e.g., Enūma elǐs IV 29; BRM IV 12, 68 and 70); 194: MS B may read i-na-á] šs-št'(PI) naptan kibräti; 197: omission of ina; 200-1 ("200”): Lambert's MSS A and B also write this in two lines, with nüh(u) previously lost at the beginning of 201 .

In the colophon the patronym is a problem. Could bu-kúr be a cryptogram for a divine name? With the family name compare, e.g., the scribal ancestor lúpa-šlu in Neo-and Late Babylonian documents from Borsippa, as indexed in F. Joannès, Archives de Borsippa. La famille Ea-ilutabâni (Geneva, 1989), p. 414. The phrase ul qati, "it is not finished," demonstrates that at Sippar, as in Aššrbanipal's libraries, the Šamaš Hymn was part of a series which continued with at least one other composition.

\section{A tablet of proverbs}

This tablet, from Niche $5 \mathrm{C}$ of the library, is complete save for its bottom left-hand corner. It is inscribed with what appear to be eleven proverbial sayings - some of them may be riddles 
(11. 11-14, 15?) - and a colophon. Dr Al-Rawi's copy was made in Baghdad, directly from the tablet. The following transliteration is provisional, pending a future collation; for the moment much of the text remains unintelligible, at least to us.

Sippar Library 5.C.4. Copy: Fig. 8

1 hi-it-x x-a-nu iš-x x iš lišs/gam na kal $\langle s i\rangle ?-i t$ ar-hi

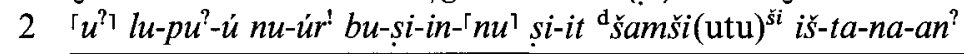

3 i-ba-'-i-ma-`a še-el-bi ${ }^{\top} k i-m a^{\top}$ im-hul-lum

4 u šu-ra-nu la ta-ri-x [(x x x) ]x-išs šá-al-lu'-tim

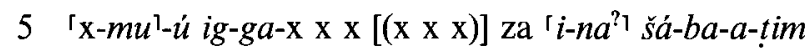

$6 u$ níg.na i-tak-pu? $u^{?} \times \mathrm{x}$-ri izakkara $(\mathrm{mu})^{r a}$ kul-li-zu

7 「ina $\mathrm{x} \mathrm{x}^{\top}$ h̆ur-šú-ú h̆u-um-si-ri ${ }^{\top} u g-d a^{\top}-m a r$ ú-na-a-ti

8 u pe-ru-ru-tú ina ášs-lu-uk-ku iš-ta-kan mi-tik-ti

$9 z u-u m-b u-\dot{u}$ šá $\times 1 \times \times{ }^{\top} \dot{u}^{1}-n i / s a l-l u$ na-qab-š́

10 u nim-mul- li $\mathrm{x} \mathrm{x}^{1}$ ti-ik šamê $(\mathrm{an})^{e} \dot{u}$-liš er-pe-e-tú

$11 \times$ x x x x x ik-pu-ú $g u-\check{s} u-r u$

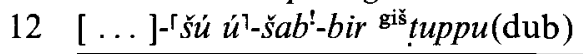

13 [ . . . ]-mi ik-nu-šú dūr (bàd) abni $\left(\mathrm{na}_{4}\right)$

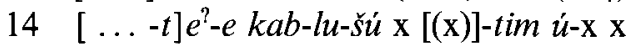

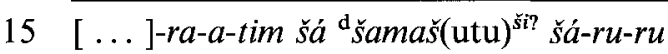

$16 \mathrm{AD}[\mathrm{x}(\mathrm{x}) \mathrm{x}] \mathrm{x} \times \dot{u}$-su-〈ù $\rangle$ ? ul-la-nišs! a-pa-a-tim

$17 u$ u kab-tu? ma-「ak'-kur lu-li-mu e-mi! ki-i šá-a-šú-un

18 liš-tah-ha-nu pa-at kul-lat ri-it-pa-šú nu-úr dšamši(utu) ${ }^{\text {ši }}$

19 si-it ar-hi \{ras.?\} ib-tar-ra-a i-mat-ti mi'-i-ni

20 ina re-e-eq 「zêeri(še.numun)?' u me-ri-i in-na-ši-ir ḩé-gál-la

21 u kab-`tu ma-ak'-kur lu-li-mu ir-ta-ši mi-ti-tum

22 nu-ub-tim šá i-na șip-pat lal-la-ri im-ták-sú

23 i-ra-ši șip-pat u ṣe-mi-ir ka-ras-su

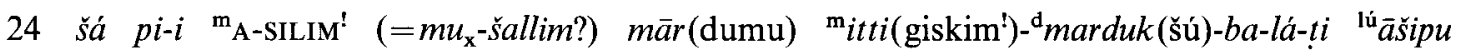
(ka.pirig.ga)

25 nippurû(nibru) ${ }^{\mathbf{k}-u ̈} a-n a$ pi-i ša-tir

1 ........ moonlight:

2 and oil, the light of the lamp-wick, rivals the sunlight.

3 Does the fox yowl like a tempest?

4 and is not the wild cat ...... captivity?

5 ......... when sweeping,

6 and the brazier ...... says the ox-driver.

7 In the ... pantry a rat has ruined the utensils,

8 and a mouse has caused losses in the storeroom.

9 The fly ...... all of it,

10 and the gnat ... raindrop ... clouds.

11 ..... became rounded: a beam;

$12[\ldots .$.$] smashed: a tablet.$

13 [..... bowed down: a wall of stone;

$14 \quad[\ldots .$.$] its \operatorname{leg} \ldots$

$15[\ldots] \ldots$ of the sun: sunbeams;

$16[\ldots] \ldots$ they went outside by the windows,

17 and the weighty property of the Stag was become like them. 


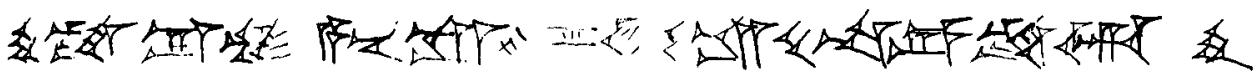

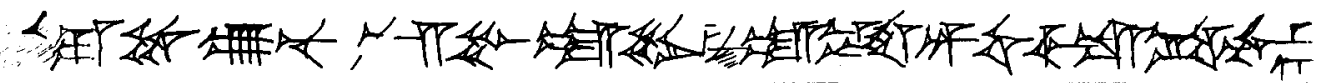

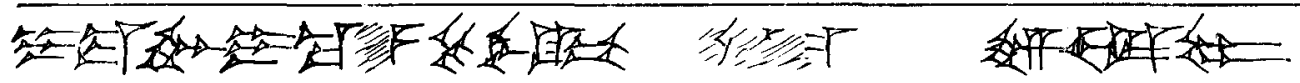

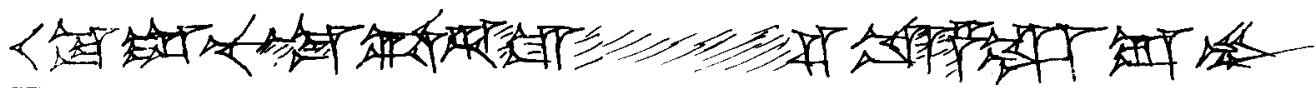

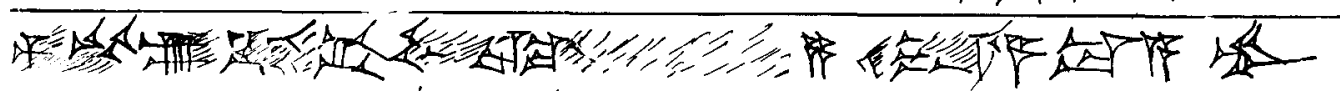



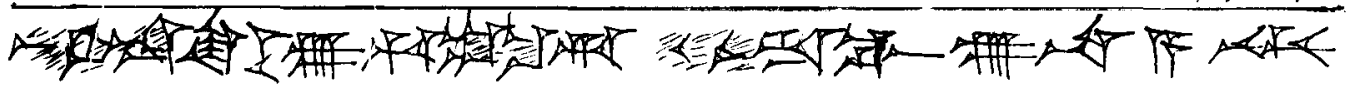

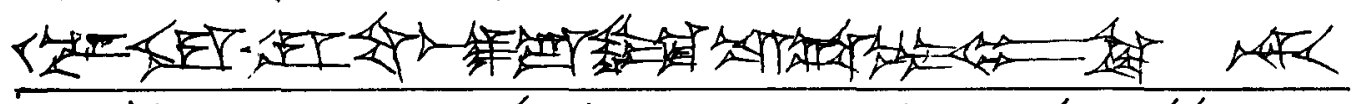

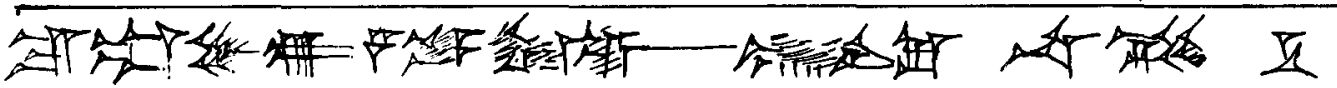

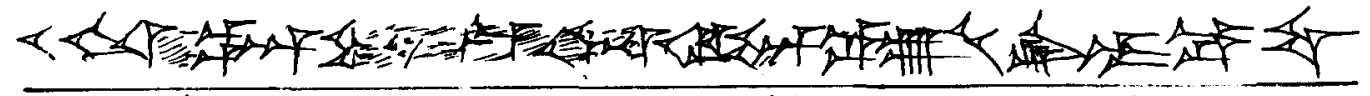

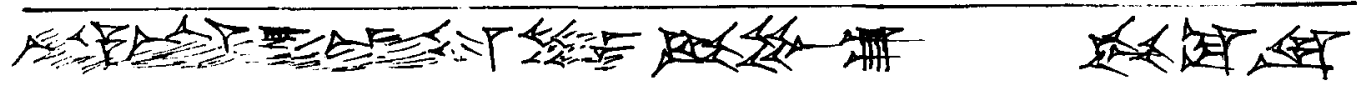

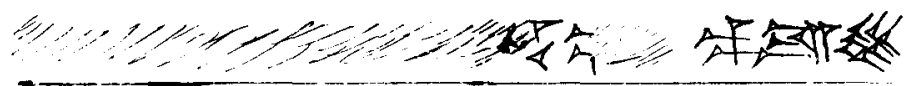

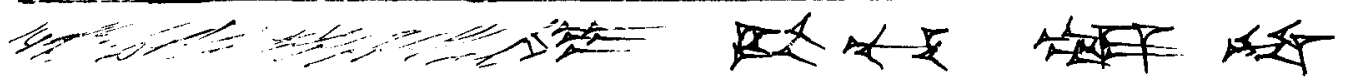

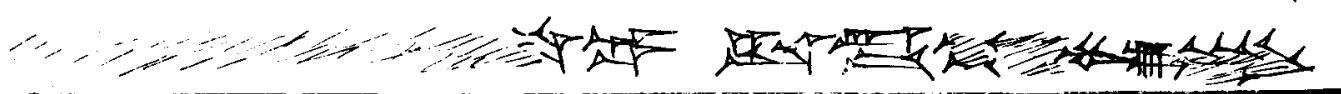

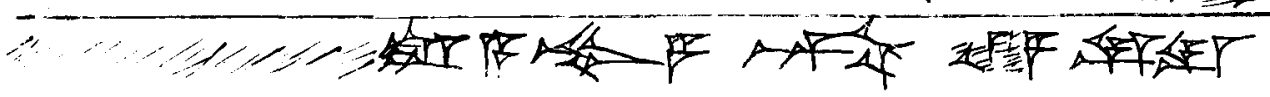

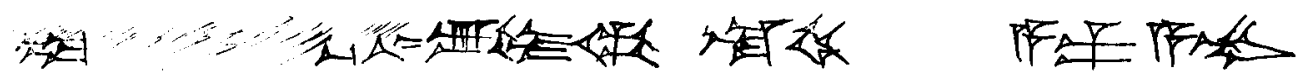

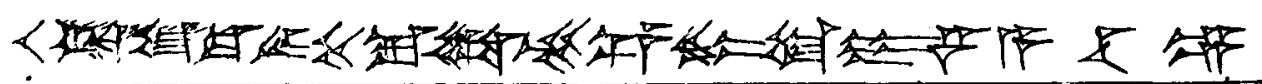

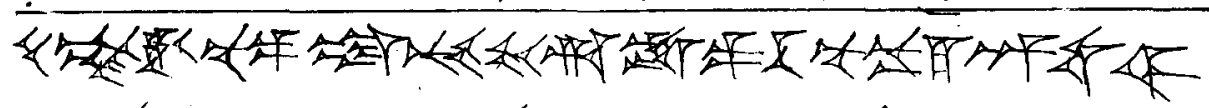

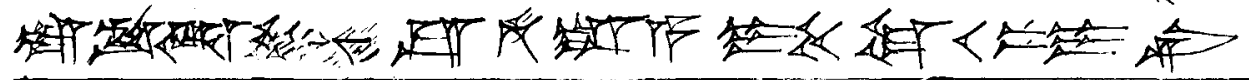

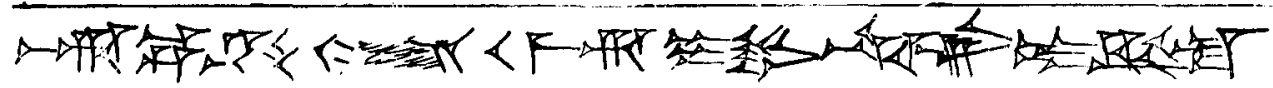

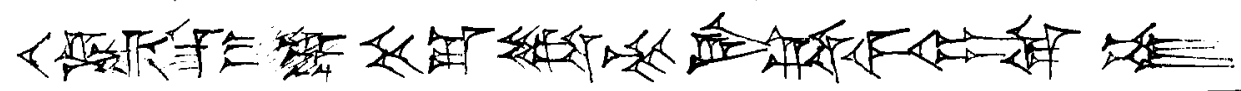

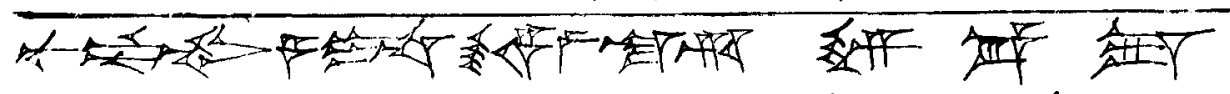
整不还

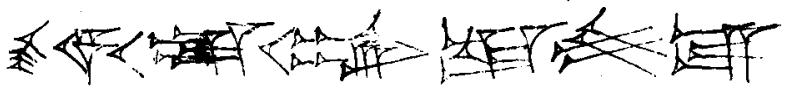

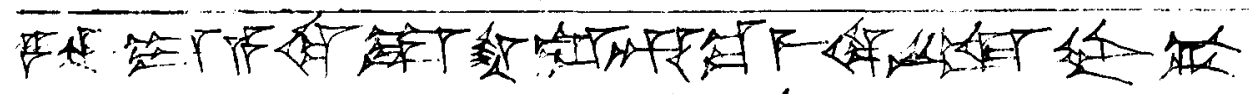

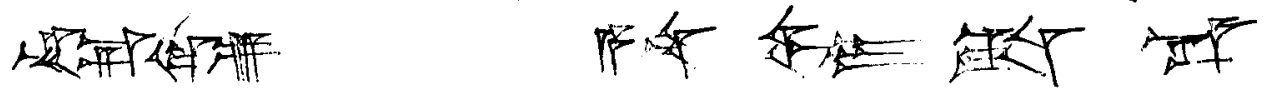


18 Though the whole world warms itself in the broad light of the sun,

19 they view the moonlight, (and say) "Why does it diminish?"

20 As conception and pregnancy were removed fertility was reduced:

21 even the weighty property of the Stag suffered a shortage.

22 The bee that collected honey in the orchard:

23 it owns the orchard and its belly is swollen.

24 From the mouth of Mušallim(?), son of Itti-Marduk-balāțu, the exorcist ${ }^{25}$ from Nippur. Written as told.

\section{Notes}

3. The translation assumes an onomatopoeic verb $b a^{\prime} \hat{u}$; cf. English "bay".

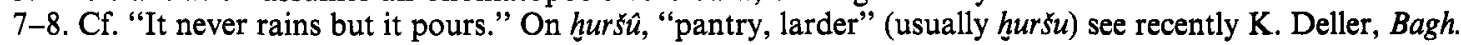
Mitt. 16 (1985), pp. $354 \mathrm{ff}$. As far as we know, the masculine variant of the well-known astukkatu appears here for the first time.

10. Flies which congregate like stars ( $\mathrm{n} \mathrm{m}, \mathrm{mul}$ ) suggest to us gnats or midges. These are, of course, partial to cool, damp air (nim-mul-lu are typically observed in the city moat, according to Šumma a $l u$ LXI: $C T$ 3921,166 ), which may be the context here too.

17, 21. The Stag is the king, as used by Sennacherib, Aššurbanipal and Nabonidus, and made explicit in the lexical equation lu-li-mu=šar-ru (Malku I 3). The "weighty property" of kings is a cliché: see the omen apodosis $K A R$ 460, 6: makkūrr(níg.ga)-š́̆ kabta(idim) ana eka[lli-ka tušerreb], "You will bring (a rival king's) weighty property into your palace."

20. The phrase zéru u méru is restored from a prayer to Sîn (STT 57, 65 and dupls.; references collected in $C A D \mathrm{M} / 2$, p. 27).

22-3. Cf. "Fortune helps those who help themselves."

24-5. The name of the son appears to be cryptically written. As well as Mušallim, one could also read Aplašullim, or similar. As for the father, the PN x-Marduk-balāțu can only be Itti-Marduk-balātu, and so the signs that precede the divine name have to be read IGI $+\mathrm{DUB}=\mathrm{g}$ is kim, i.e. construct state of $i t t u$. The orthography of both names is intentionally recherché, given the predilection of Late Babylonian scribes for what might be called "clever" writing and cryptography. 